\title{
Penggunaan Sumber Belajar Digital Exelsa Moodle dan Komik Toondo Dalam Meningkatkan Kreativitas Belajar Sejarah
}

\author{
Brigida Intan Printina*
}

\begin{abstract}
Abstrak
Pembelajaran sejarah saat ini menjadi sangat penting bagi dunia pendidikan. Semakin banyak masyarakat yang tidak menyadari jati dirinya sebagai warga negara Indonesia karena tidak memiliki pengetahuan tentang perjuangan bangsa di masa lalu.Penyampaian pesan masa lalu dapat dikemas dengan menarik jika para pendidik sejarah mau bertransformasi lewat media pembelajaran tanpa menghilangkan esensi dari nilai dan karater bangsa. Menyadari betapa kencangnya arus teknologi dan digitalisasi peneliti ingin membuka konseksi untuk memanfaatkan media sebagai bahan penunjang pembelajaran sejarah. Penelitian ini bertujuan untuk mengkaji penggunaan sumber belajar digital lewat exelsa moodle dan komik Toondo sebagai sarana yang tepat menggali sejarah secara efektif dan mampu meningkatkan kreativitas belajar yang sudah diujikan di Universitas Sanata Dharma khusunya pada mata kuliah Multimedia Pembelajaran Sejarah dan Sejarah Gereja. Jenis penelitian ini adalah Penelitian Tindakan Kelas. Metode penelitian dilakukan melalui dua siklus, dimulai dari perencanaan, pelaksanaan, observasi, refleksi, dan dilanjutkan dengan perencanaan siklus berikutnya. Hasil penelitian mengungkapkan bahwa media pembelajaran sejarah melalui Exelsa Moodle dan Komik Toondo memberi pengaruh yang besar bagi kreativitas peserta didik dan pembelajaran sejarah dapat divisualisasikan dengan mudah sehingga lebih menarik dan inovatif baik bagi pengajar maupun peserta didik.
\end{abstract}

\section{Kata Kunci: Digital Exelsa Moodle, Komik Toondo, Kreatifitas}

\section{Pendahuluan}

Teknologi sangat mendukung penyampaian informasi yang instan sesuai dengan tuntutan zaman yang transformatif. Filsuf Yunani bernama Plato memunculkan wacana teknologi ketika karyanya Republik dan Phaedros membahas soal seni dan penemuan dari kata "techne" yaitu menunjuk pada pengetahuan indrawi (aesthetic) dalam upaya menghasilkan sesuatu yang berbeda sebagai bahan baku (craft), yang kemudian kita kenal sebagai "kreasi". ${ }^{1}$ Berdasarkan observasi awal untuk

1 Tommy F Awuy, Teknologi Digital dan Budaya Kontemporer, dibawakan dalam Seminar Dosen Dies Natalis Universitas Sanata Dharma ke-61 meneliti tentang pelaksanaan pembelajaran sejarah ternyata terdapat beberapa masalah di kelas dimana para mahasiswa tidak terbiasa menggunakan media pembelajaran termasuk exelsa karena Sejarah Kawasan atau mata kuliah teori jarang menggunakan media e-learning termasuk exelsa.

Pada mata kuliah sejarah kawasan terlihat ada kekurangan pada perkuliahan awal, khususnya dalam kegiatan pembelajaran.Beberapa mahasiswa terbiasa mendengarkan penjelasan dan berdiskusi seolah sudah menjadi tradisi.Maka peneliti

dengan tema "Cerdas dan Humanis di Era Digital" 
berinisiatif untuk melakukan tindakan untuk memaksimalkan penggunaan media serta meningkatkan kreativitas mahasiswa pada mata kuliah Sejarah Gereja.

Sebagai calon pendidik, mahasiswa tidak hanya dituntut kritis dalam menanggapi berbagai informasi namun juga memiliki keterampilan dalam melihat situasi dan kondisi lingkungan yang dihadapinya kelak.Kondisi lingkungan yang mampu menunjang ialah kondisi yang membangkitkan peserta didik untuk dapat kreatif, aktif, dan inspiratif, sehingga membuat pembelajaran menjadi menyenangkan dan bermanfaat.Kreativitas peserta didik tampak dalam usahanya menggali informasi secara kritis dan menganalisis berbagai peristiwa lebih mendalam.

Penelitian ini mengguanakan Classroom Action Research dimana bentuk kajian bersifat reflektif dilakukan untuk memperbaiki dan meningkatkan kualitas pembelajaran sengan menggunakan tindakan tertentu.Penelitian dilakukan dalam dua siklus.Masing-masing siklus terdiri dari empat tahap yaitu perencanaan, tindakan, pelaksanaan, observasi dan refleksi.

Seperti yang digambarkan di atas, penelitian tindakan kelas ini difokuskan pada bentuk dan skenario pembelajaran yang efektif dengan menggunakan sarana yang baik dan mempermudah dosen dalam mengajar.Penelitian ini dilakukan pada mahasiswa semester VI Prodi Pendidikan Sejarah Universitas Sanata Dharma namun ada beberapa mahasiswa yang shoper.

\section{Tinjauan Pustaka}

Exelsa Moodle merupakan e-learning yang ditawarkan oleh P3MP (Sekarang PPIP) sebagai pengelola sumber belajar digital dalam mendukung upaya Universitas Sanata Dharma (USD) untuk meningkatkan peringkat webomatrics dengan membuka akses sumber belajar digital secara luas kepada publik.Peringkat webomatrics sangat memikat perhatian masyarakat akademis sebagai salah satu indikator aksesibilitas website. $^{2}$

Sejak USD bergabung dengan Association of Christian Universities and colleges in Asia (ACUCA) pada tahun 2008, USD merasa perlu untuk membangun Learning Management System (LMS) berbasis moodle. Tujuannya adalah membangun sistem pembelajaran agar dapat berinteraksi dengan sistem pembelajaran di semua perguruan tinggi lain yang tergabung dalam keanggotaan ACUCA.

Sejalan dengan pengembangan LMS, Renstra USD 2013 hl.58, sasaran 3.3 secara jelas dan eksplisit juga menggariskan pentingny pengembangan digital learning resource berbasis keilmuan dan kompetensi, yang sejalan dnegan

\footnotetext{
2 Buku Panduan Exelsa Berbasis Moodle untuk Dosen
} 
Permendikbud No. 109 th. 2013 tentang PJJ PT yang menggariskan pentingnya pengembangan sumber belajar digitl dan LMS dalam pengolaan berbagai komponen pembelajaran, yang nantinya secara pelan maupun pasti mebarag pada era e-learning ${ }^{3}$

Komik Toondoo merupakan media pembelajaran berbasis online dengan website www.toondoo.com. Pada website tersebut, pengguna dapat membuat dan menyusun materi pembelajaran dalam bentuk komik, mengambil atau membuat tokoh kartun yang sudah tersedia atau membuat tokoh karakter sendiri. ${ }^{4}$ Ada beberapa fasilitas yang disediakan oleh Toondoo yaitu:

a. Toon Doomaker: untuk membuat kartun atau komik berupa satu halaman yang dapat ditentukan terlebih dahulu layoutnya, misalkan satu halaman untuk 1-4 adegan secara vertikal atau horizontal.

b. Bookmaker: fasilitas ini disediakan untuk menyusun komik kecil yang sudah dibuat menjadi sebuah buku

c. TraitR: fasilitas untuk membuat karakter kartun yang baru

d. ImagineR: fasilitas untuk mengupload dan mengedit gambar dari pengguna

3 E. Sunarto. Prototipe Disain Pengembangan Matakuliah Vocabulary berbasis Exelsa Moodle, Yogyakarta: PBI USD, diuraikan dalam Buku Implementasi Pengembangan Sumber Belajar Digital tahun 2015

${ }^{4}$ www.toondoo.com e. DoodleR: fasilitas ini untuk melengkapi gambar dengan sentuhan warna sesuai keinginan pengguna

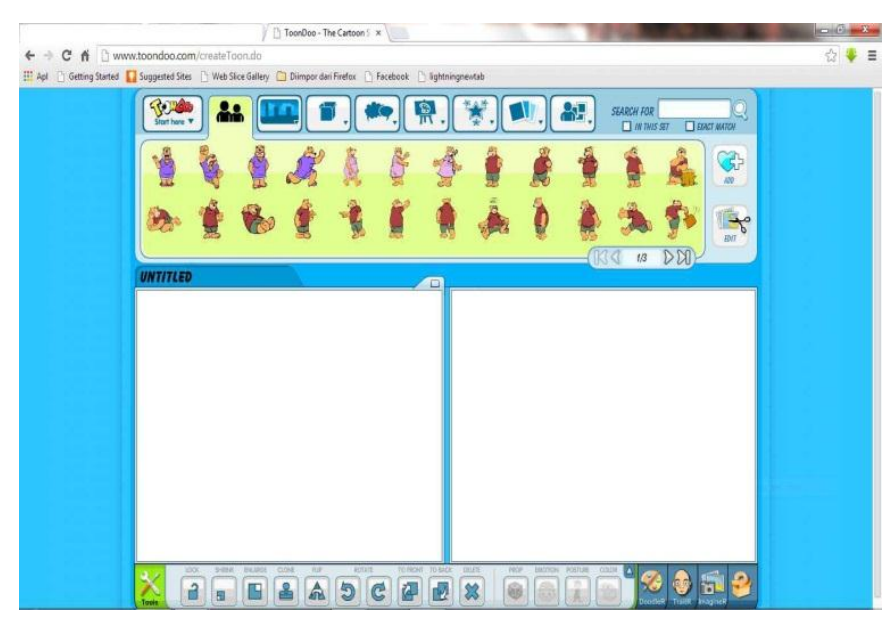

Gambar 1 Area Kerja Toondoomaker Keterangan :

a. Menubar: berisi kumpulan menu yang memiliki beragam fungsi.

b. Toolbar: tampilan perintah yang berupa simbol

c. Lembar kerja: tempat untuk menambahkan dan menyusun background, karakter (gambar), teks, dan sebagainya.

d. Task Pane: terdiri dari character, background, props, texts, bushmen, special, open clip art, dan my gallery dimana tanda segitiga yang terdapat di setiap pilihan itu memungkinkan mengakses berbagai macam gambar yang dapat ditambahkan dalam lembar kerja.

Menurut NACCCE (National Advisory Committee on Creative and Cultural Education) (dalam Craft, 2005), kreativitas adalah aktivitas imaginatif yang 
menghasilkan hasil yang baru dan bernilai. Selanjutnya Feldman (dalam Craft, 2005) mendefinisikan kreativitas adalah:

The achievement of something remarkable and new, something which transforms and changes a field of endeavor in a significant way ... the kinds of things that people do that change the world.

Menurut Munandar (1985), kreativitas adalah kemampuan untuk membuat kombinasi baru, berdasarkan data, informasi atau unsur-unsur yang ada. Hasil yang diciptakan tidak selalu hal-hal yang baru, tetapi juga dapat berupa gabungan (kombinasi) dari hal-hal yang sudah ada sebelumnya.Selain itu, Csikszentmihalyi (dalam Clegg, 2008) menyatakan kreativitas sebagai suatu tindakan, ide, atau produk yang mengganti sesuatu yang lama menjadi sesuatu yang baru.

Guilford (dalam Munandar, 2009) menyatakan kreativitas merupakan kemampuan berpikir divergen atau pemikiran menjajaki bermacam-macam alternatif jawaban terhadap suatu persoalan, yang sama benarnya (Guilford, dalam Munandar 2009). Sedangkan menurut Rogers (dalam Zulkarnain, 2002), kreativitas merupakan kecenderungankecenderungan manusia untuk mengaktualisasikan dirinya sesuai dengan kemampuan yang dimilikinya.

Ada rumusan yang dikeluarkan oleh Departemen Pendidikan Nasional, bahwa indikator peserta didik yang memiliki kreativitas, yaitu:

a. Memiliki rasa inging tahu yang besar,

b. Sering mengajukan pertanyaan yang berbobot,

c. Memberikan bnyak gagasan dan usul dalam suatu masalah, mampu menyatakan pendapat secara spontan dan tidak malu-malu,

d. Mempunyai dan menghargai rasa keindahan,

e. Mempunyai pendapat sendiri dan dapat mengungkapkannya, tidak terpengaruh orang lain,

f. Memiliki rasa humor tinggi,

g. Mempunyai daya imajinasi yang kuat,

h. Mampu mengajukan pemikiran, gagasan pemecahan masalah yang berbeda dari orang lain (orisinal),

i. Dapat bekerja sendiri

j. Senang mencoba hal-hal baru,

k. Mampu mengembangkan atau memerinci suatu gagasan (kemampuan elaborasi)

\section{Metode Penelitian}

Penelitian ini dilakukan di Ruang II/K-32 kampus 1 Universitas Sanata Dharma Yogyakarta. Penelitian dilakukan pada perkuliahan Sejarah Gereja dengan subyek penelitian adalah mahasiswa semester VI Program Studi Pendidikan Sejarah FKIP USD. Obyek penelitian ini ialah penggunaan exelsa moodle dan media komik toondoo pada mata kuliah Sejarah Gereja. 
Penelitian ini menggunakan jenis Penelitian Tindakan Kelas (Classroom Action Research) model Kemmis-Taggart (1988). Model Kemmis-Taggart (dalam Rochiati, 2010: 66) menjelaskan 4 tahap penelitian dimulai perencanaan, pelaksanaan, observasi dan refleksi.

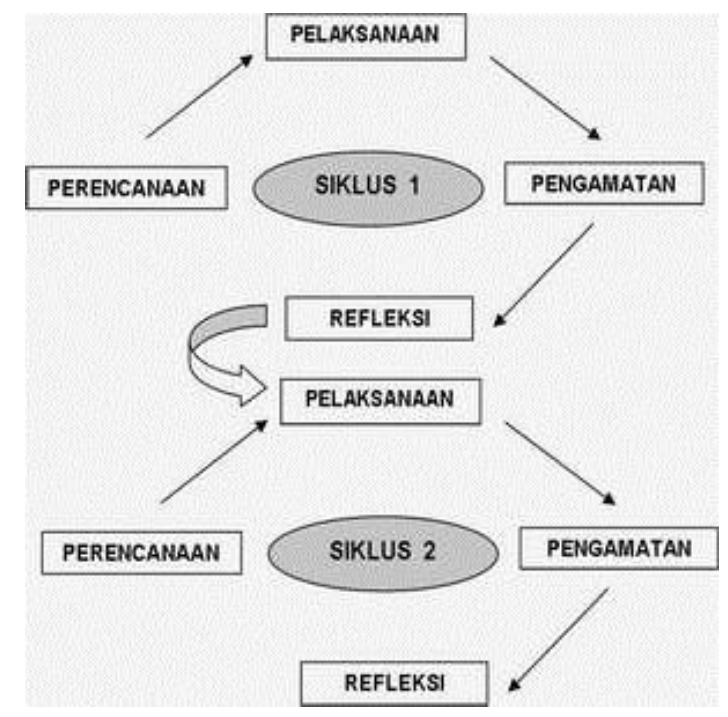

Gambar 2. Siklus Peneltiian Tindakan Kelas

\section{Kemmis-Taggart}

Tahap perencenaan merupakan tahap dimana peneliti membuat instrument penelitian dan pengajaran. Instrument penelitian berupa observasi dan kuesioner, sedangkan instrument pengajaran berupa perangkat pembelajaran seperti RPS, RTP, dan RTP.

Pelaksanaan penelitian dilakukan melalui dua tahap yaitu siklus I dan siklus II.Siklus I materi yang digunakan untuk USIP 1 sedangkan siklus II materi yang digunakan untuk USIP 2. Pengamatan dilakukan sendiri oleh penelitia dengan menggunakan instrument observasi. Pengamatan dilakukan pada saat penugasan kelompok saat persentasi mahasiswa menggunakan media komik Toondo, dan ketepatan dalam pengumpulan tugas melalui exelsa moodle.

Teknik pengumpulan data dalam penelitian ini adalah observasi, angket/ kuesioner, dan tes. Observasi dilakukan untuk mengumpulkan data tentang tingkat kemampuan kreativitas mahasiswa. Refleksi dilakukan oleh dosen dan mahasiswa untuk mengukur sejauh mana dosen dapat mencapai tujuan pembelajaran Sejarah Gereja dalam penelitian ini.

Penelitian yang berjudul Penggunaan Exelsa Moodle dan Media Komik Toondoo dalam Meningkatkan Kemampuan Berpikir Kritis dan Kreativitas Mahasiswa Pada Mata Kuliah Sejarah Gereja dilakukan dengan menggunalakan langkah penelitian tindakan kelas:

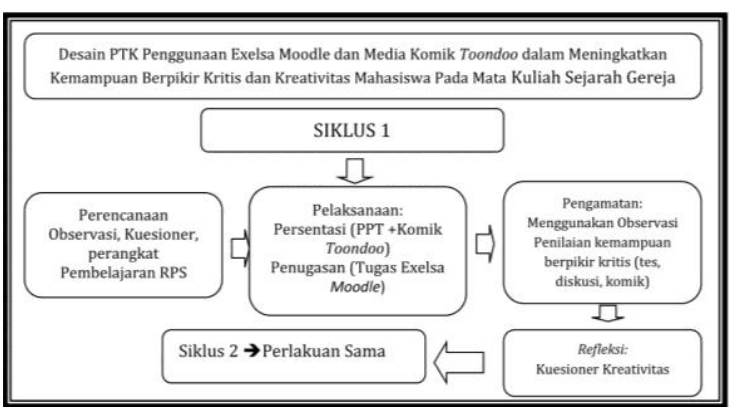

Gambar 3. Langkah penelitian tindakan kelas

\section{Hasil Dan Pembahasan}

Classroom Action Research ialah suatu bentuk kajian bersifat reflektif oleh peneltii yang dilakukan untuk memperbaiki dan meningkatkan kualitas pembelajaran dengan melakukan tindakan tertentu. Penelitian biasanya dilakukan dalam dua siklus. Masing-masing siklus terdiri dari 
empat tahap, yaitu perencanaan, Pada pertemuan 1 hingga 4 Dosen pengamatan, aksi dan refleksi.

PTK dilaksanakan pada perkualiahan Sejarah Gereja di Ruang K.30 Kampus 1 Mrican Universitas Sanata Dharma Yogyakarta pada semester VI tahun ajaran 2016/2017. Tujuan melakukan penelitian pada mata kuliah ini ialah:

a. Mengukur kemampuan berpikir kritis mahasiswa pendidikan sejarah di semester VI dalam mengimplementasi pembelajaran Sejarah Gereja lewat media pembelajaran.

b. Mengukur kreativitas mahasiswa pendidikan sejarah di semester VI dalam menggunakan sumber belajar digital berbasis Exelsa Moodle dengan menggunakan Komik Toondo

Mengingat masih banyak guru yang kurang kreatif dalam pembelajaran sejarah maka dengan penggunaan sumber belajar digital ini guru di masa mendatang agar tidak gentar menggunakan media dalam pengajaran sejarah.

Total Jumlah Mahasiswa ialah 64 orang yang tidak mengikuti perkuliahan dari awal ialah 1 orang, sehingga total anggota kelompok ada 63 orang.

Pertemuan dilakukan sebanyak 16 kali pada pertemuan.2 kali pertemuan untuk USIP 1 dan USIP 2.Sedangkan 14 kali pertemuan diantaranya 9 pertemuan persentasi dan 5 pertemuan untuk pengantar dan peneguhan pemahaman materi. memberikan materi mengenai Sejarah Gereja Perdana.Materi diunduh lewat program exelsa materi pertemuan satu dan dua menjelaskan kemunduran Romawi. Kemunduran Romawi ditandai dengan adanya peperangan dengan bangsa Yunani. Namun bangsa Romawi kembali bangkit saat menjalani hubungan baik yang ditandai dengan Kode Moral bagi bangsa Yahudi untuk tinggal termasuk didaerah kekuasaan Romawi salah satunya Yerusalem.

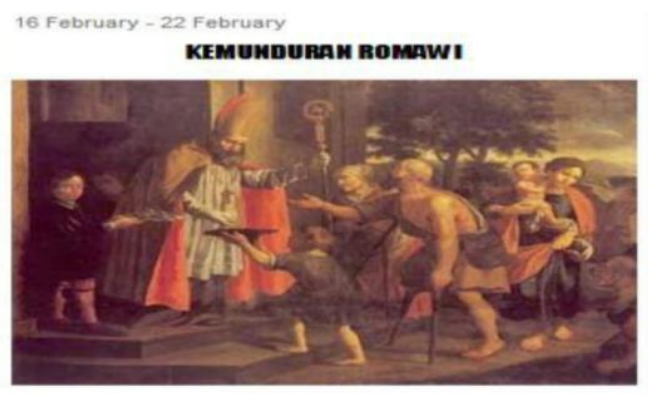

Gambar 4.Tampilan pada layar Exelsa, kemunduran Romawi dan pengaruhnya bagi gereja.

Pada pertemuan ke 3 dan ke 4 dosen memberikan penjeasan tentang perkembangan Gereja pada Abad Pertengahan. Dosen memberikan penjelasan dimana sumber yang digunakan ialah Buku yang berjudul "Gereja Sepanjang Masa" karangan Embuiru. Awal abad pertengahan, 590-1048: ditandai dengan kebijakan pontifikatus Gregorius Agung hingga pembentukan kemakmuran bersama umat Kristen di Eropa pada abad XI. Awal abad pertengahan, 590-1048: ditandai dengan kebijakan pontifikatus Gregorius Agung 
hingga pembentukan kemakmuran bersama umat Kristen di Eropa pada abad XI.

Selain terdapat kegiatan misionaris oleh bangsa German dan Slavia, juga terdapat invasi pemasukan barbar ke wilayah Eopa barat; Islam menghapus bersih agama Kristen di Afrika utara, menyebar ke Eropa selatan, hingga berhenti di Spanyol. Para paus harus mempertahankan kekuasaannya terhadap patriak Konstantinopel, sedangkan di Roma para paus harus menerima kuasa duniawi dari tangan Frank. Pada abad X kepausan terlibat dalam kegelapan diaman kekaisaran Karoling runtuh, dan digantikan oleh kekairsaran Roma Suci.

Pertengahan abad pertengahan.Dari tokoh Hildebrand hingga Bonifatius VIII 1048-1294. Ini merupakan jangka waktu kerajaan paus dengan kekaisaran Roma Suci; terjadi perang salib yang pertama, mulai lahir sekolah Kristen, persatuan biarawan awam, kesenian dan arsitektur Roma dan Gota. Akhir abad pertengahan 1294-1517, revolusi dimulai dan ditandai dengan pemisahan kuasa duniawi dan rohani. Kuasa politik kekaisaran dan perkembangan negara-negara baru; pertentangan paus dan raja-raja Perancis, Skisma besar di barat, kemunduran filsafat dan teologi Kristen, hidup kembali kesenian dan kesusasteraan purba. Masa ini mengalami kekacauan dalam hal politik dan agama.
Berikut merupakan tampilan materi pada layar exelsa:
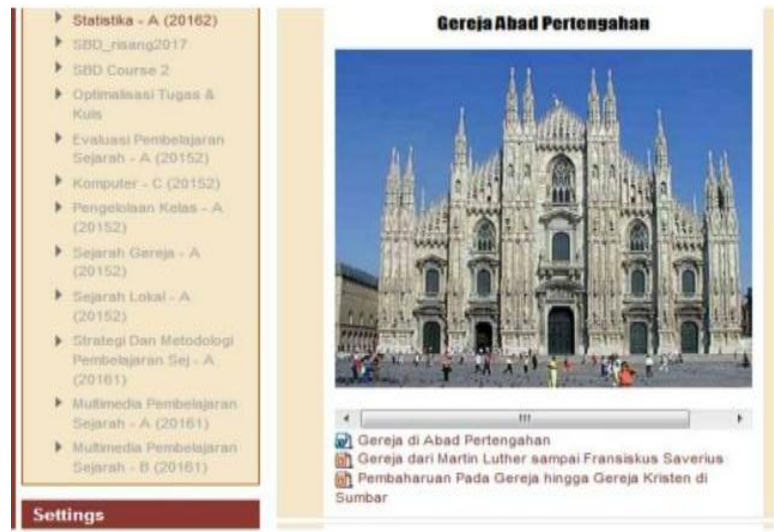

Gambar 5.Tampilan pada layar Exelsa,

Perkembangan gereja pada abad pertengahan.

Berikut merupakan hasil dari pengembangan exelsa Moodle dan Aplikasi Toondo: Perkembangan sejarah Gereja Belanda yang nantinya berdampak bagi perkembangan pekabaran injil Kristen di Indoneisa. Berikut merupakan kisahnya dalam bentuk aplikasi Toondo.
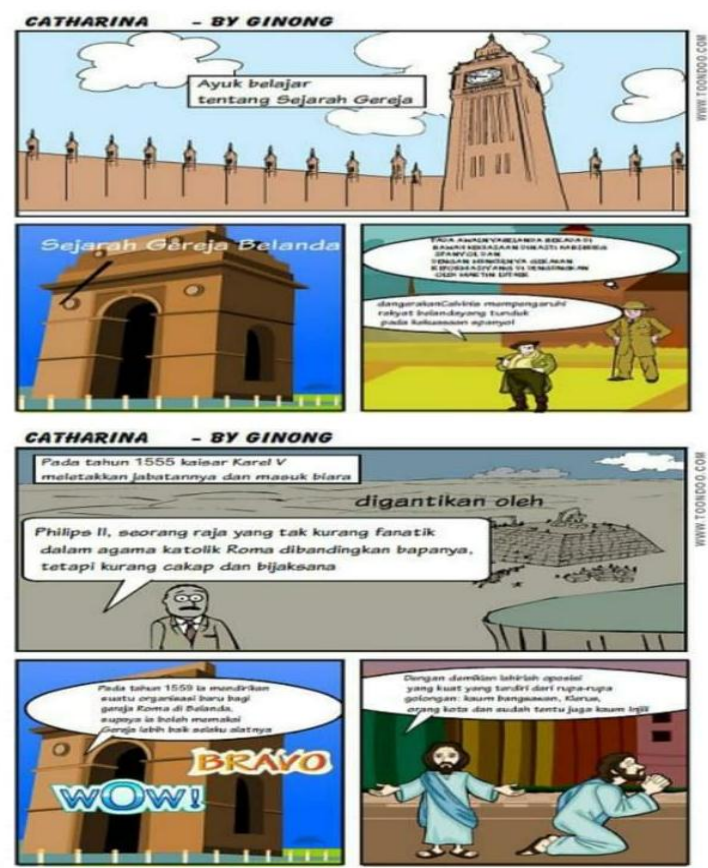

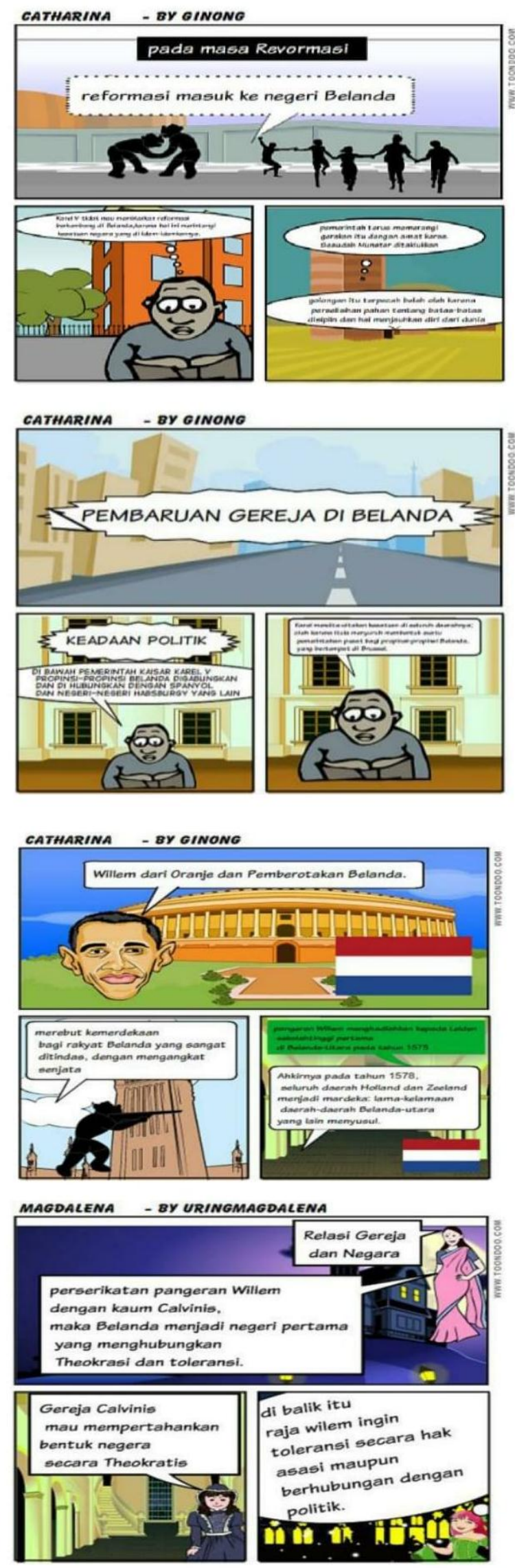
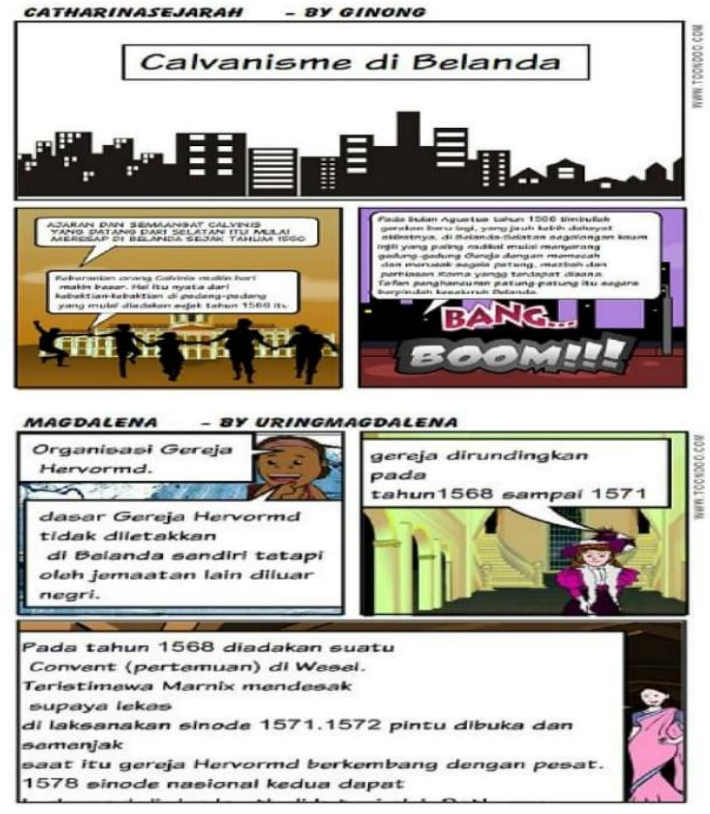

Gambar 6. Sejarah perkembangan gereja

Belanda dan pengkabaran Injil dalam aplikasi Tondoo

Dari beberapa gambar tersebut dapat dijelaskan secara singkat bahwa Belanda mendapat pengaruh Kristen Calvinis yang kuat.Sebelumnya usaha penaklukan Spanyol atas Belanda mengurungkan niat warganya untuk tetap mengimani Katolik karena Spanyol ingin mengkatolikkan Belanda semata-mata untuk penguasaan wilayah. Maka dengan pasukan Inggris yang dipimpin oleh Willem Orange ia membatu raja Philip II untuk melindungi Belanda dari jajahan Spanyol.

Hal ini berdampak pada keyakinan masyarakat akan keselamatan yang dibawa oleh Inggris yang sesungguhnya menganut ajaran Gereja Reformasi berpengaruh pula pada masyarakat yang beralih pada Gereja Reformasi. Adapun tokoh Reformasi Gereja yang sangat diteladani di Belanda ialah 
Calvinis sebagai penerus Martin Luther. Namun Calvinis memiliki keyakinan lain dimana untuk mendapatkan keselamatan setiap orang harus bekerja keras di dunia.

Apabila manusia bisa sukses di dunia maka sukses pula di akhirat. Maka ajarannya ini berlaku pula bagi pemerintahan Belanda dimana setiap orang harus berkeyakinan Calvinis. Segala tata pemerintahan harus sesuai dengan aturan gereja. Maka lahirlah apa yang disebut 'ibu gereja' dimana setiap utusan, pegawai, atau pekabar injil di luar negeri Belanda hendaknya mentaati semua aturan 'ibu gereja'. Hal ini pula yang mempengaruhi tata pemerintahan dan gereja pada masa penjajahan Belanda di Indonesia.

Kemudian ada kelompok yang mempresentasikan perkembangan Gereja di Sumatera. Gereja di sini berkembang pasca VOC runtuh. Maka Gereja yang berkembang ialah Huria Kritesten Batak Protestan (HKBP). Ada beberapa zending (lembaga Kristen) yang berkembang baik dari Belanda, Jerman, dan AS.

Beberapa zending berkembang karena pekabaran injil yang dilakukan Belanda tidak dapat diresapi karena para pegawai yang tidak dapat menjangkau seluruh wilayah, serta fokus pekerjaan yang dilakukan karena tidak dapat menyamakan keadaan di Nusantara dan Belanda yang mengharuskan setiap pegawai menggunakan aturan 'ibu negara'.
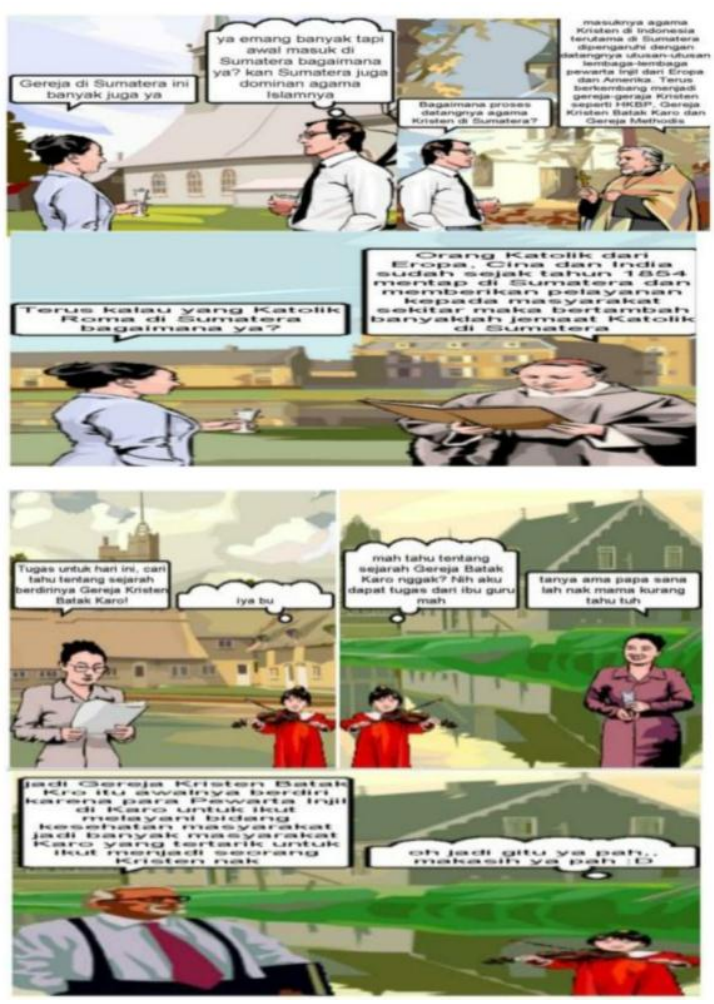

Seperti yang telah direncanakan sebelumnya bahwa akan dilakukan pengukuran tingkat kerativitas mahasiswa pada mata kuliah Sejarah Gereja Untuk mengukur tingkat kreativitas mahasiswa Dosen menggunakan aplikasi google form untuk pengisian kuesioner mata kuliah khususnya Sejarah Gereja. Berikut merupkan contoh form kuesioner:

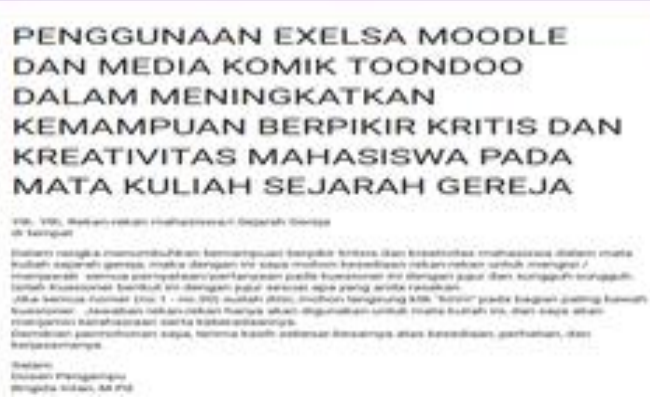

Gambar 7. Form kuesioner lewat google form

Aplikasi ini memperlihatkan berapa respon mahasiswa yang telah menjawab 
dan setiap soal langsung teridentifikasi berapa besar persentase kevalidannya. Hasil akan dilampirkan. Dengan menggunakan aplikasi ini memudahkan dosen untuk melakukan analisis data yang dilakukan menggunakan Ms. Exel. Untuk mengukur validitas dan reabilitas dosen menggunakan rumus corelation yang ada pada Ms. Exel:

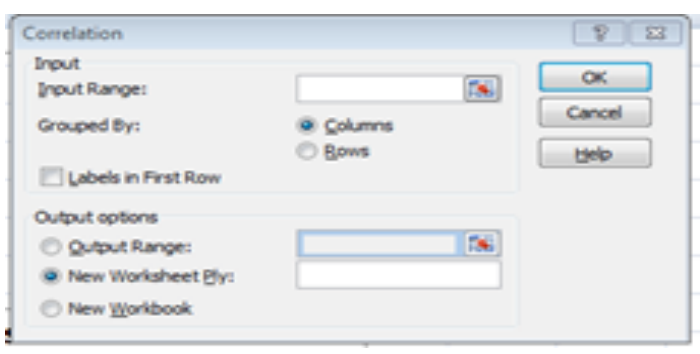

Gambar 8. Input data validitas dan reabilitas data kuesioner

Setelah dihitung validitas tingkat kreativitas mahasiswa pada mata kuliah Sejarah Gereja dengan menggunakan Sumber Belajar Digital Exelsa Moodle dan Komik Toondo maka didapat hasil sebagai berikut:

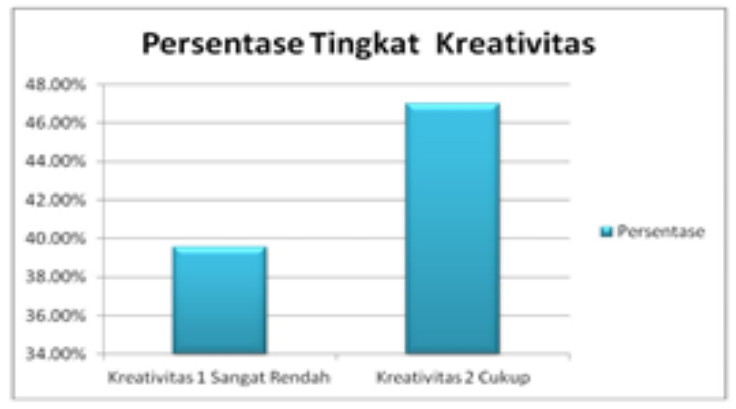

Gambar 9. Komparasi Diagram frekuensi tingkat validitas kreativitas mahasiswa

Dari diagram di atas dapat diuraikan bahwa persentase tingkat kreativitas mahasiswa ialah sebesar $7.47 \%$. Ini menunjukkan bahwa tingkat kreativitas mahasiswa pada mata kuliah ini
meningkat.Meski pada awalnya mereka tidak menunjukkan kreatvitias yang berarti bahwa menyamakan Sejarah Gereja dengan mata kuliah sejarah kawasan lainya dengan kegiatan diskusi dan persentasi.Tingkat kreativitas mahasiswa meningkat setelah menggunakan exelsa moodle dan aplikasi Komik Toondo.

\section{Penutup}

\section{A. Kesimpulan}

Penggunaan sumber belajar digital melalui exelsa moodle dan aplikasi Komik Toondo menjadi salah satu media yang dapat digunakan untuk membangkitkan semangat belajar sejarah. Penelitian yang dilakukan pada suatu mata kuliah sejarah kawasan yang memiliki teori yang mendalam pun memerlukan sarana agar pada saat ini pengajar dan peserta didik dapat berkolaborasi dengan baik dengan pengajaran.

Adapun hasil kuantitatif yang didapat untuk mengukur kreativitas peserta didik ialah dengan menggunakan instrument kuesioner atau angket dimana disana ditunjukkan bahwa terdapat peningkatan kreativitas pada mahasiswa sebesar $7.47 \%$. Dengan demikian para pengajar tidak perlu khawatir untuk mengkoneksikan pengajaran sejarah dengan media pembalajaran yang menawarkan berbagai sarana pembelajaran yang inovatif dan menarik minat belajar khususnya belajar sejarah. 


\section{Daftar Pustaka}

Ana Craft. 2005. Membangun Kreativitas Anak. Depok: Insani Press.

Arikunto, Suharsimi. 2006. Prosedur Penelitian Suatu Pendekatan Praktik. Jakarta: Rineka Cipta.

Buku Panduan Exelsa Berbasis Moodle untuk Dosen

Clegg, P. 2008. Creativity and Critical Thingking The Globalised University. Innovation in Education and Teaching International Vol.45, No.3.Taylor \& Francis.

Embuiru, S.V.D., H. 1961, Gereja Sepanjang Masa, Ende, Penerbit Nusa Indah

End, Thomas van den, tt, Harta Dalam Bejana, Sejarah Gereja Ringkas, Jakarta, BPK Gunung MUlia

Kemmis, S. dan Taggart, R. 1988. The Action Research Planner. Deakin:Deakin University

Munandar, S.C.U. 1985. Mengembangkan Bakat dan Kreativitas Anak Sekolah. Grasindo: Jakarta.

Munandar, Utami. 2009. Pengembangan Kreativitas Anak Berbakat. Jakarta: Rineka Cipta

Neni Fitriawati. Penerapan model Pembelajaran Berbasis Masalah (Problem Based Learning) dalam meningkatkan Kemampuan Berpikir Kritis Siswa pada Mata Pelajaran IPS Terpadu kelas VII di MTsN Selorejo Blitar (UIN Maulana Malik Ibrahim Malang, 2010), h.36

Sunarto, E. Prototipe Disain Pengembangan Matakuliah Vocabulary berbasis Exelsa Moodle. Yogyakarta: PBI USD, diuraikan dalam Buku Implementasi Pengembangan Sumber Belajar Digital tahun 2015

Tommy F Awuy, Teknologi Digital dan Budaya Kontemporer, dibawakan dalam Seminar Dosen Dies Natalis Universitas Sanata Dharma ke-61 dengan tema "Cerdas dan Humanis di Era Digital"

Verhaak S.J., Chr., 1987, Sejarah Perkembangan Iman Dari Awal Sampai Dengan Masa Kini Dan Sejarah Perkembangan Iman di Indonesia, Yogyakarta, Sekolah Tinggi Filsafat Kateketik "Pradnyawidya".

Wiriatmadja, Rochiati. 2010. Model Penelitian Tindakan Kelas untuk Meningkatkan Kinerja Guru dan Dosen. Bandung: Roddakarya

www.toondoo.com 